\title{
STUDIES ON (-)-CITRAMALIC ACID FORMATION BY RESPIRATION-DEFICIENT YEAST MUTANTS ${ }^{1}$
}

\section{CITRAMALIC ACID FORMATION AND A VARIETY OF RESPIRATION-DEFICIENT STRAINS OF BREWER'S, BAKER'S, SAKE, AND WINE YEASTS}

\author{
TOSHIYUKI SAI AND MIKIO AMAHA \\ Central Research Laboratories, Asahi Breweries Ltd., \\ Sumida-ku, Tokyo
}

(Received October 29, 1966)

\begin{abstract}
Sixteen RD mutant strains of Saccharomyces carlsbergensis and Saccharomyces cerevisiae, which were isolated by spontaneous mutation, acriflavine treatment, and ultraviolet irradiation, were studied for their ability to produce citramalic acid in a chemically defined medium. It was found that all those RD "petite" mutants which were clearly judged to be respiration-deficient in any of the four criteria, i.e. oxygen uptake, coloration of colonies on BCG agar, TTC reduction, and lactate utilization, did accumulate citramalate abundantly (13 to $46 \mathrm{mg}$ per 100 $\mathrm{ml}$ of medium). None of the seven parent normal strains tested produced citramalic acid. Some variants isolated on BCG agar (verdant and variegated types), which were positive in reducing TTC, were not able to produce citramalic acid.

RD mutant haploid strains of known cytochrome pattern (baker's yeast) were found to be divided into the citramalate formers and nonformers, but it was not possible to relate their citramalate-producing abilities to the kind of deficient cytochromes.
\end{abstract}

In the previous work (1), it was found that the RD mutant strains of Saccharomyces carlsbergensis accumulated an unknown acid during fermentation in a chemically defined medium containing glucose. The unknown acid was isolated in a crystalline form and finally identified as (-)-citramalic acid.

Among the RD mutants of yeasts, it has been stated, with respect to genetic behavior, that there exist vegetative (cytoplasmic), segregational (nuclear), and double mutants which have undergone mutation in both cytoplasmic factor and nuclear gene. Vegetative $\mathrm{RD}$ mutants which lack the

1 Abbreviations used in this text are as follows: RD mutant, respirationdeficient mutant; BCG, bromocresol green; TTC, 2, 3, 5-triphenyltetrazolium chloride. 
cytoplasmic self-reproducing factor $\rho$, required for development of respiratory enzymes, are produced in a high frequency by exposure to acriflavine or related dyes and ultraviolet irradiation, and various kinds of mutants are also derived by these treatments (2-5).

In the present work, the accumulation of citramalic acid by various $R D$ mutants of yeast was studied in connection with their respiratory defects.

\section{MATERIALS AND METHODS}

Organisms. Four strains of Saccharomyces carlsbergensis (brewer's yeast), three strains of Saccharomyces cerevisiae (baker's, Sake, and wine yeasts) were used as the starting strains for the spontaneous and artificial mutations. Strains of $\mathrm{R}_{2} \mathrm{O}$ and $\mathrm{R}_{2} \mathrm{Q}$ series are haploid segregants from a diploid strain of baker's yeast, Saccharomyces cerevisiae, which were supplied by the courtesy of Dr. T. Sugimura from the stock cultures of the National Cancer Center Research Institute of Japan. These haploid strains are designated as $\mathrm{R}_{2} \mathrm{O} 1 \mathrm{~B}, \mathrm{R}_{2} \mathrm{O} 1 \mathrm{~B}-\mathrm{AF}, \mathrm{R}_{2} \mathrm{O} 2 \mathrm{C}, \mathrm{R}_{2} \mathrm{O} 5 \mathrm{~A}, \mathrm{R}_{2} \mathrm{O} 3 \mathrm{~B}, \mathrm{R}_{2} \mathrm{Q} 2 \mathrm{~B}-\alpha_{0}, \mathrm{R}_{2} \mathrm{Q} 2 \mathrm{~B}-\alpha_{1}$, and $\mathrm{R}_{2} \mathrm{Q} 2 \mathrm{~B}-\alpha_{2}$. The two strains $\mathrm{R}_{2} \mathrm{O} 1 \mathrm{~B}$ and $\mathrm{R}_{2} \mathrm{Q} 2 \mathrm{~B}-\alpha_{0}$ are normal with respect to respiratory characteristics. $\mathrm{R}_{2} \mathrm{O} 1 \mathrm{~B}-\mathrm{AF}$ (vegetative petite), $\mathrm{R}_{2} \mathrm{O} 3 \mathrm{~B}$ (segregational petite), $\mathrm{R}_{2} \mathrm{Q} 2 \mathrm{~B}-\alpha_{1}$ (vegetative petite) and $\mathrm{R}_{2} \mathrm{O} 2 \mathrm{~B}-\alpha_{2}$ (vegetative petite) possess only cytochrome $c$ and lack cytochromes $a$ and $b . \quad \mathrm{R}_{2} \mathrm{O} \quad 2 \mathrm{C}$ (segregational petite) and $\mathrm{R}_{2} \mathrm{O} 5 \mathrm{~A}$ (segregational petite) are devoid of cytochromes $a, b$, and $c$, and accumulate porphyrins in yeast cells $(6)$. Since these haploid RD strains had been originally isolated by Dr. N. GUNGE in terms of their inability to reduce triphenyltetrazolium chloride (TTC) (5), their coloration characteristics on a bromocresol-green containing agar medium (BCG agar) were found to be somewhat diverse, as will be described later.

Induction of mutation and isolation of mutants. RD mutants were derived from the wild type strains by spontaneous mutation, acriflavine treatment, and ultraviolet irradiation. Spontaneous RD mutants were isolated by plating a diluted cell suspension of the parent strains on the surface of a BCG agar. The BCG agar employed was essentially the same with Difco's W. L. nutrient medium, and contained (per 1) yeast extract $(4 \mathrm{~g})$, peptone $(5 \mathrm{~g})$, glucose $(50 \mathrm{~g}), \mathrm{KH}_{2} \mathrm{PO}_{4}(0.55 \mathrm{~g}), \mathrm{KCl}(0.425 \mathrm{~g}), \mathrm{CaCl}_{2} \cdot 2 \mathrm{H}_{2} \mathrm{O}(0.125 \mathrm{~g})$, $\mathrm{MgSO}_{4} \cdot 7 \mathrm{H}_{2} \mathrm{O}(0.125 \mathrm{~g}), \mathrm{FeCl}_{3} \cdot 6 \mathrm{H}_{2} \mathrm{O}(2.5 \mathrm{mg}), \mathrm{MnSO}_{4} \cdot 4 \mathrm{H}_{2} \mathrm{O}(2.5 \mathrm{mg})$, agar $(15 \mathrm{~g})$, and $\mathrm{BCG}(22 \mathrm{mg})$. The $\mathrm{pH}$ of medium was adjusted to 5.5 prior to autoclaving. After incubation on this BCG agar for 4 to 7 days at $25^{\circ}$, RD mutants appear as white-edged colonies with dark green central areas, as opposed to the whitish or light green colonies of normal respiration-competent strains $(7,8)$. Acriflavine-induced RD mutants were isolated by inoculating the parent cells onto the surface of the BCG agar plates to which acriflavine had been previously added in final concentrations of 5 to $50 \mu \mathrm{g}$ per ml. For obtaining ultraviolet-induced $\mathrm{RD}$ mutants, the cells of parent strains were heavily inoculated onto the surface of BCG agar plates, irradiated with ultraviolet rays (Toshiba 
sterilizing lamp GL-10) from a distance of $50 \mathrm{~cm}$ for 2 to $5 \mathrm{~min}$, and incubated for 5 to 7 days at $25^{\circ}$. RD mutant clones were selected at random from the agar plates by the BCG color differentiation of yeast colonies. All these $\mathrm{RD}$ mutants did not revert to the original form during serial transfer for more than one year.

Confirmation of respiration deficiency of mutants. BCG agar surface plating method $(7,8)$, TTC-agar-overlay method (9), test for the ability to utilize lactate for growth (10), and conventional Warburg manometry were used to confirm the respiration deficiency of mutants.

The yeast cells used for the Warburg manometry were statically cultivated in $500 \mathrm{ml}$ Erlenmeyer flasks containing $180 \mathrm{ml}$ of a liquid medium for $48 \mathrm{hr}$ at $25^{\circ}$. The medium consisting of Yeast Nitrogen Base (Difco) and $2.5 \%$ glucose was supplemented with L-lysine $(10 \mathrm{mg} / \mathrm{liter})$. Cells were removed by centrifugation from the culture fluids, washed twice with $\mathrm{M} / 20$ phosphate buffer ( $\mathrm{pH} 4.5$ ) and suspended in the same buffer. The oxygen uptake of intact cells was determined in the conventional Warburg vessels at $25^{\circ}$. Incubation mixture in the vessel contained $0.2 \mathrm{ml}$ of $10 \%$ glucose, $1.6 \mathrm{ml}$ of $\mathrm{M} / 20$ phosphate buffer ( $\mathrm{pH} 4.5$ ) and 2 to $5 \mathrm{mg}$ dry weight of yeast cells in a final volume of $2.8 \mathrm{ml}$. To the side arm and the center well of the vessels $0.2 \mathrm{ml}$ of $30 \% \mathrm{KOH}$ was added, and $\mathrm{Q}_{02}^{\text {air }}$ was expressed as $\mu$ l of oxygen consumed per mg dry weight of yeast cells per hr.

Cultivation for citramalic acid determination. The Yeast Nitrogen Base (Difco) medium containing $5 \%$ glucose was inoculated with yeast strains from the slant cultures and statically cultivated for 6 days at $25^{\circ}$. This medium was supplemented with L-lysine $(10 \mathrm{mg} /$ liter $)$. L-Lysine had no effect on the accumulation of citramalic acid by $\mathrm{RD}$ mutants, but it was required for the growth of some of the haploid RD mutants used.

Analysis of citramalic acid. An aliquot of the fermentation broth from which cells were removed by centrifugation was employed for citramalic

Table 1. Amount of citramalic acid determined by iodometry and silica gel chromatography.

\begin{tabular}{c|c|c}
\hline \multirow{2}{*}{ Sample $^{a}$} & \multicolumn{2}{|c}{ Citramalic acid $(\mathrm{mg} / 100 \mathrm{ml}$ of medium) } \\
\cline { 2 - 3 } & Iodometry $^{b}$ & $\begin{array}{c}\text { Silica gel } \\
\text { chromatography }\end{array}$ \\
\hline No. 1 & 9.9 & 10.3 \\
No. 2 & 3.9 & 4.3 \\
No. 3 & 16.9 & 21.0 \\
No. 4 & 44.4 & 49.0 \\
\hline
\end{tabular}

a The Yeast Nitrogen Base media containing 5\% glucose were fermented by the three different yeast strains.

$b$ Corrected for the recovery. 
acid determination. Since simple and specific method for the determination of citramalic acid has not yet been devised, the method of DIMOTAKI-KOURAKOU (11), which has been used for the estimation of citramalic acid in wine, was adopted in this work. In this method, samples were first adsorbed on an ion-exchange resin (Dowex-1 X2, acetate form), and eluted with $2.5 \mathrm{~N}$ acetic acid. The eluted fraction containing citramalic acid (but not citric acid) was subjected to permanganate oxidation. Acetone formed from citramalic acid was estimated by iodometry according to the method of KogAN-PENAUd (12). Recovery of citramalic acid by this procedure was proved to be about $80 \%$ in all the experiments. This method was compared with the silica gel chromatography (1) and the results obtained by the two methods were almost identical, as shown in Table 1.

\section{RESULTS}

Citramalic acid accumulation and the respiratory characteristics of normal parent strains of brewer's, baker's, and wine yeasts were first examined. As can be seen in Table 2, all the seven parent strains tested produced only negligible amounts of citramalic acid and gave higher $\mathrm{Q}_{\mathrm{O}_{2}}$ values, compared to their RD mutant strains (cf. Table 3).

Table 2. Citramalic acid accumulation and respiratory characteristics of normal parent strains of yeast.

\begin{tabular}{|c|c|c|c|c|c|}
\hline $\begin{array}{c}\text { Parent } \\
\text { strain }\end{array}$ & $\begin{array}{c}\text { Citramalic } \\
\text { acid formed } \\
(\mathrm{mg} / 100 \mathrm{ml} \\
\text { of medium })\end{array}$ & $\underset{\substack{\text { cell } / \mathrm{hr} \\
(\mu \mathrm{mo}}}{\mathrm{mg}_{2} \mathrm{dry}}$ & $\begin{array}{l}\text { Lactate }^{a} \\
\text { utili- } \\
\text { zation }\end{array}$ & $\begin{array}{l}\text { TTC } \\
\text { reduc- } \\
\text { tion }^{b}\end{array}$ & $\begin{array}{l}\text { Coloration of } \\
\text { colonies on BCG } \\
\text { agar medium }\end{array}$ \\
\hline $\begin{array}{l}\text { Brewer's yeast } \\
\text { strain A }\end{array}$ & 1.1 & 9.0 & + & + & white to light green \\
\hline $\begin{array}{l}\text { Brewer's yeast } \\
\text { strain JS }\end{array}$ & 1.3 & 7.6 & + & + & white to light green \\
\hline $\begin{array}{l}\text { Brewer's yeast } \\
\text { strain } 776\end{array}$ & 2.3 & 4.8 & + & + & white to light green \\
\hline $\begin{array}{l}\text { Brewer's yeast } \\
\text { strain S }\end{array}$ & 1.5 & 8.0 & + & + & white to light green \\
\hline $\begin{array}{l}\text { Baker's yeast } \\
\text { strain T }\end{array}$ & 2.2 & 6.0 & + & + & white to light green \\
\hline $\begin{array}{l}\text { Sake yeast } \\
\text { strain SH4-6 }\end{array}$ & 1.4 & 6.1 & + & + & white to light green \\
\hline $\begin{array}{l}\text { Wine yeast } \\
\text { strain OC- } 2\end{array}$ & 3.3 & 8.9 & + & + & white to light green \\
\hline
\end{tabular}

a Growth in liquid medium containing $2.0 \%$ sodium lactate as the sole source of carbon.

$b$ The colonies grown on yeast-extract peptone glucose agar medium for 3 days at $25^{\circ}$ were overlaid with the medium consisting of TTC $(0.05 \%)$, glucose $(0.5 \%)$, and agar $(1.0 \%)$ in phosphate buffer $(\mathrm{pH} 7.0)$, and incubated for 1 to 3 hr at $25^{\circ}$. 
Table 3. Citramalic acid accumulation by spontaneously derived mutants of brewer's and wine yeast, and their respiratory characteristics.

\begin{tabular}{|c|c|c|c|c|c|c|}
\hline $\begin{array}{l}\text { Mutant } \\
\text { strain }\end{array}$ & $\begin{array}{l}\text { Parent } \\
\text { strain }\end{array}$ & $\begin{array}{c}\text { Citramalic } \\
\text { acid formed } \\
\text { ( } \mathrm{mg} / 100 \mathrm{ml} \\
\text { of medium }\end{array}$ & $\begin{array}{c}\mathrm{Q}_{2} \\
(\mu \mathrm{l} / \mathrm{mg} \\
\mathrm{dry} \\
\text { cell } / \mathrm{hr})\end{array}$ & $\begin{array}{c}\text { Lactate } \\
\text { utili- } \\
\text { zation }\end{array}$ & $\begin{array}{l}\text { TTC } \\
\text { reduc- } \\
\text { tion }\end{array}$ & $\begin{array}{l}\text { Coloration of colonies } \\
\text { on BCG agar medium }\end{array}$ \\
\hline $\begin{array}{l}\text { A-1 } \\
\text { (petite) }\end{array}$ & A & 13.2 & 0.6 & - & - & $\begin{array}{l}\text { white border with dark } \\
\text { green central area }\end{array}$ \\
\hline $\begin{array}{l}\text { A-2 } \\
\text { (variegated) }\end{array}$ & A & 0 & - & - & + & green sectors \\
\hline $\begin{array}{l}\text { A-3 } \\
\text { (verdant) }\end{array}$ & A & 0.3 & - & - & + & light green \\
\hline $\begin{array}{l}\text { JS-1 } \\
\text { (petite) }\end{array}$ & JS & 12.8 & 0.7 & - & - & $\begin{array}{l}\text { white border with dark } \\
\text { green central area }\end{array}$ \\
\hline $\begin{array}{l}776-1 \\
\text { (petite) }\end{array}$ & 776 & 15.4 & 1.5 & - & + & $\begin{array}{l}\text { white border with dark } \\
\text { green central area }\end{array}$ \\
\hline $\begin{array}{l}\text { S-1 } \\
\text { (petite) }\end{array}$ & $\mathrm{S}$ & 14.5 & 0.6 & - & - & $\begin{array}{l}\text { white border with green } \\
\text { central area }\end{array}$ \\
\hline $\begin{array}{l}\text { OC-2-1 } \\
\text { (petite) }\end{array}$ & $\mathrm{OC}-2$ & 46.6 & 0.1 & - & - & $\begin{array}{l}\text { white border with green } \\
\text { central area }\end{array}$ \\
\hline
\end{tabular}

Table 4. Citramalic acid accumulation by acriflavine-induced and ultraviolet-induced mutant strains, and their respiratory characteristics.

\begin{tabular}{|c|c|c|c|c|c|c|}
\hline $\begin{array}{l}\text { Mutant } \\
\text { strain }\end{array}$ & $\begin{array}{l}\text { Parent } \\
\text { strain }\end{array}$ & $\begin{array}{l}\text { Citramalic } \\
\text { acid formed } \\
\text { (mg/100 } \mathrm{ml} \\
\text { of medium) }\end{array}$ & $\begin{array}{c}\mathrm{Qo}_{2} \\
(\mu \mathrm{l} / \mathrm{mg} \\
\mathrm{dry} \\
\text { cell } / \mathrm{hr}\end{array}$ & $\begin{array}{c}\text { Lactate } \\
\text { utili- } \\
\text { zation }\end{array}$ & $\begin{array}{l}\text { TTC } \\
\text { reduc- } \\
\text { tion }\end{array}$ & $\begin{array}{l}\text { Coloration of colonies } \\
\text { on BCG agar medium }\end{array}$ \\
\hline $\begin{array}{l}\text { SH4-6-1 } \\
\text { (petite) }\end{array}$ & SH4-6 & 31.1 & 0.4 & - & - & $\begin{array}{l}\text { white border with blue } \\
\text { central area }\end{array}$ \\
\hline $\begin{array}{l}\mathrm{SH} 4-6-2 \\
\text { (petite) }\end{array}$ & SH4-6 & 31.6 & 0.4 & - & - & $\begin{array}{l}\text { white border with blue } \\
\text { central area }\end{array}$ \\
\hline $\begin{array}{l}\text { SH4-6-3 } \\
\text { (haploid) }\end{array}$ & SH4-6 & 1.0 & 5.1 & + & + & $\begin{array}{l}\text { white to light green } \\
\text { and rough-edged }\end{array}$ \\
\hline $\begin{array}{l}\text { SH4-6-5a } \\
\text { (petite) }\end{array}$ & SH4-6 & 26.6 & 1.6 & - & - & $\begin{array}{l}\text { white border with blue } \\
\text { central area }\end{array}$ \\
\hline $\begin{array}{l}\mathrm{T}-1 \\
\text { (petite) }\end{array}$ & $\mathrm{T}$ & 33.4 & 1.2 & - & - & $\begin{array}{l}\text { white border with light } \\
\text { green central area }\end{array}$ \\
\hline $\begin{array}{l}\mathrm{T}-2 \\
\text { (petite) }\end{array}$ & $\mathrm{T}$ & 26.1 & - & - & - & $\begin{array}{l}\text { white border with dark } \\
\text { green central area }\end{array}$ \\
\hline $\begin{array}{l}\mathrm{T}-3 \\
\text { (verdant) }\end{array}$ & $\mathrm{T}$ & 0.8 & 4.4 & + & + & green \\
\hline
\end{tabular}

a This strain was induced by ultraviolet irradiation. Other mutant strains were all induced by acriflavine treatment. 
Table 5. Citramalic acid accumulation by haploid strains of $\mathrm{R}_{2} \mathrm{O}$ and $R_{2} \mathrm{Q}$ series of baker's yeast, and their respiratory characteristics.

\begin{tabular}{|c|c|c|c|c|c|}
\hline $\begin{array}{l}\text { Yeast } \\
\text { strain }\end{array}$ & $\begin{array}{l}\text { Citramalic } \\
\text { acid formed } \\
(\mathrm{mg} / 100 \mathrm{ml} \\
\text { of medium })\end{array}$ & $\begin{array}{l}\mathrm{QO}_{2} \\
(\mu \mathrm{l} / \mathrm{mg} \\
\mathrm{dry} \\
\text { cell } / \mathrm{hr}\end{array}$ & $\begin{array}{c}\text { Lactate } \\
\text { utili- } \\
\text { zation }\end{array}$ & $\begin{array}{l}\text { TTC } \\
\text { reduc- } \\
\text { tion }\end{array}$ & $\begin{array}{l}\text { Coloration of colonies } \\
\text { on BCG agar medium }\end{array}$ \\
\hline $\begin{array}{l}\mathrm{R}_{2} \mathrm{O} \quad 1 \mathrm{~B} \\
\text { (normal) }\end{array}$ & 1.0 & 5.3 & + & + & white to light green \\
\hline $\begin{array}{l}\mathrm{R}_{2} \mathrm{O} \text { 1B-AF } \\
\text { (petite) }\end{array}$ & 11.7 & 1.2 & - & - & $\begin{array}{l}\text { white border with green } \\
\text { central area }\end{array}$ \\
\hline $\begin{array}{l}\mathrm{R}_{2} \mathrm{O} 2 \mathrm{C} \\
\text { (petite) }\end{array}$ & 12.1 & 0.6 & 一 & - & $\begin{array}{l}\text { white border with green } \\
\text { central area }\end{array}$ \\
\hline $\begin{array}{l}\mathrm{R}_{2} \mathrm{O} 5 \mathrm{~A} \\
\text { (petite) }\end{array}$ & 2.3 & 0.6 & - & - & dark green \\
\hline $\begin{array}{l}\mathrm{R}_{2} \mathrm{O} \text { 3B } \\
\text { (petite) }\end{array}$ & 0.5 & 0.4 & - & - & $\begin{array}{l}\text { white with green stripes; } \\
\text { after } 10 \text { days, white } \\
\text { border with green central } \\
\text { area }\end{array}$ \\
\hline $\begin{array}{l}\mathrm{R}_{2} \mathrm{Q} 2 \mathrm{~B}-\alpha_{0} \\
\text { (normal) }\end{array}$ & 1.2 & 1.1 & + & + & white to light green \\
\hline $\begin{array}{l}\mathrm{R}_{2} \mathrm{Q} 2 \mathrm{~B}-\alpha_{1} \\
\text { (petite) }\end{array}$ & 9.6 & 0.8 & - & - & $\begin{array}{l}\text { white border with green- } \\
\text { striped central area }\end{array}$ \\
\hline $\begin{array}{l}\mathrm{R}_{2} \mathrm{Q} \\
\text { (petite) }\end{array}$ & 8.5 & 1.2 & - & - & $\begin{array}{l}\text { white border with green- } \\
\text { striped central area }\end{array}$ \\
\hline
\end{tabular}

Production of citramalic acid by mutant strains of different origin and their respiratory characteristics are tabulated in Tables 3,4 and 5 . The petite mutant strains (A-1, JS-1, 776-1, S-1 and OC-2-1) which were derived spontaneously from normal strains and diagnosed as "petite" by coloration on BCG agar produced a large amount of citramalic acid (13 to $46 \mathrm{mg}$ citramalic acid per $100 \mathrm{ml}$ of medium). They had much lower $\mathrm{Q}_{0_{2}}$ values $(0.1$ to $1.5 \mu \mathrm{l}$ per $\mathrm{mg}$ dry weight of cells per $\mathrm{hr}$ at $25^{\circ}$ ) than their respective normal strains $\left(\mathrm{Q}_{\mathrm{O}_{2}}=4.8\right.$ to $\left.9.0 \mu \mathrm{l}\right)$, and they were all negative in TTC reduction and lactate utilization, and were stained green with a white border on BCG agar. The only exception was 776-1 which was positive in TTC reduction (Table 3).

As can be seen in Table 4, the acriflavine-induced petite mutants (Sh46-1, SH4-6-2, T-1 and T-2) and the ultraviolet-induced petite mutant (SH4$6-5)$ also produced a large amount of citramalic acid and showed the same respiratory characteristics as the spontaneously derived RD mutants.

It might be of interest to note here that the petite mutant strains of Sake and baker's yeasts (SH4-6-1, SH4-6-2, SH4-6-5, T-1 and T-2), and especially the petite strain of wine yeast (OC-2-1), produced greater amount of citramalic acid than the petite mutant strains of brewer's yeast (Saccharomyces carlsbergensis).

Verdant type strains (A-3 and T-3), a variegated type strain (A-2), and a haploid type strain (SH4-6-3), as termed by CzARNECKI and VAN ENGEL for brewer's yeast ( $\boldsymbol{7})$, were also examined to see if these variants, which 
were competent or partially competent to respire, could accumulate citramalic acid. They exhibited approximately the same level of $\mathrm{Q}_{0_{2}}$ values as their parent strains and did not accumulate citramalic acid.

In the series of baker's yeast haploid strains of known cytochrome pattern (Table 5), the normal strains, $\mathrm{R}_{2} \mathrm{O} 1 \mathrm{~B}$ and $\mathrm{R}_{2} \mathrm{Q} 2 \mathrm{~B}-\alpha_{0}$, did not produce citramalic acid, while haploid petite mutants were found to be divided into two types; citramalic acid formers $\left(\mathrm{R}_{2} \mathrm{O} 1 \mathrm{~B}-\mathrm{AF}, \mathrm{R}_{2} \mathrm{O} 2 \mathrm{C}, \mathrm{R}_{2} \mathrm{Q} 2 \mathrm{~B}-\alpha_{1}\right.$, and $\mathrm{R}_{2} \mathrm{Q}$ $\left.2 \mathrm{~B}-\alpha_{2}\right)$ and non-formers $\left(\mathrm{R}_{2} \mathrm{O} 5 \mathrm{~A}\right.$ and $\left.\mathrm{R}_{2} \mathrm{O} 3 \mathrm{~B}\right)$. Contrary to our expectation, it was not possible to find out any relationship between the kind of deficient cytochromes and the citramalate-accumulating ability in these haploid strains of baker's yeast. It should be noted, however, that the strains of this series had been designated as " petite" by their inability to reduce TTC, and therefore some of them showed slightly varied coloration on BCG agar. For example, the colony of $\mathrm{R}_{2} \mathrm{O} 5 \mathrm{~A}$ on $\mathrm{BCG}$ agar was entirely dark green (verdant type-like) and that of $\mathrm{R}_{2} \mathrm{O} 3 \mathrm{~B}$ was very slow in showing the green central area which is a typical characteristics of the petite mutant.

The mutant strains which showed definitely lower oxygen uptake and were clearly judged to be respiration-deficient by their BCG coloration, TTC reduction, and lactate utilization were all capable of accumulating citramalic acid. None of parent respiration-competent strains showed accumulation of citramalic acid.

\section{DISCUSSION}

The data obtained in the present work evidently showed that the RD mutant strains which were isolated from normal strains of brewer's, baker's, Sake, and wine yeasts by spontaneous occurrence, acriflavine induction, and ultraviolet irradiation had the ability to accumulate citramalic acid. Further investigation employing haploid strains of known cytochrome pattern revealed that citramalic acid was accumulated by most of the haploid RD mutant strains with a few exceptions, while all of the normal strains tested could not accumulate this acid. On the other hand, it was found that morphological variant strains (the verdant and variegated type strains), which were differentiated by the coloration of colonies on BCG agar and were positive in TTC reduction, could not produce citramalic acid. These facts seem to indicate that the deficiency in respiratory activities is a prerequisite for the citramalate accumulation by yeast cells, and also that intermediate alterations between normal and petite mutant strains as revealed on BCG agar are not sufficient to impart the citramalate-accumulating abilities to the yeast cells.

Furthermore, the fact that some of the haploid RD mutants of baker's yeast could not accumulate citramalate even though they were negative in oxygen uptake, TTC reduction, and lactate utilization (Table 5) appears to imply that respiration deficiency does not always lead to citramalate accumulation. The correlation between respiration deficiency and citramalate accumula- 
tion will be more clearly elucidated from biochemical studies on the mechanisms of citramalate formation in RD mutant yeast cells which are under way in this laboratory.

Recently, Sherman and Slonimski (13) reported that by using various combinations of the segregational and cytoplasmic mutants of Saccharomyces cerevisiae, numerous strains having various alterations in the content of cytochromes $a, b$ and $c$ could be obtained. Avers et al. (4), who studied histochemically 59 strains of acriflavine-induced "petite" mutants of Saccharomyces cerevisiae, recognized four different phenotypes with regard to their cytochrome oxidase and succinic dehydrogenase reactions in mitochondria. The presence of a variety of RD mutant has also been described by MORITA (14) in the case of Saccharomyces cerevisiae mutants induced by 4-nitroquinoline $\mathrm{N}$-oxide. In our experiments, similar morphological or physiological diversity in RD mutants has been noticed. For example, the two haploid RD mutants of baker's yeast, $\mathrm{R}_{2} \mathrm{O} 5 \mathrm{~A}$ and $\mathrm{R}_{2} \mathrm{O} 3 \mathrm{~B}$, were somewhat different from the typical "petite" mutant strain in the coloration on BCG agar, and the spontaneously induced RD mutant strain of a brewer's yeast, 776-1, was capable of reducing TTC; the former two being unable to accumulate citramalic acid and the latter being able to accumulate the acid.

The amount of citramalic acid accumulated by RD mutants also varied widely from 13 to $46 \mathrm{mg}$ per $100 \mathrm{ml}$ of medium under the same cultural conditions. Although the RD mutants of baker's, Sake, and wine yeasts (all belonging to Saccharomyces cerevisiae) appeared to produce more citramalic acid than the RD mutants of brewer's yeast (Saccharomyces carlsbergensis), the number of yeast strains tested in the present work is not sufficient to make any definite statement regarding the ability of the RD mutant of each yeast species to produce citramalic acid. At this stage of study, it seems better to conclude that there is a diversity in the citramalate-accumulating ability among the RD mutants of each strain of the yeast.

The authors are grateful to Mr. M. NAKAJima, the President, and Mr. S. TAKAYANAGI, the Managing Director, of Asahi Breweries Ltd., for permission to publish this work. Thanks are also due to Dr. T. AsAI, Professor Emeritus of the University of Tokyo, for his encouragement throughout the work, and to Dr. T. Sugimura, National Cancer Center Research Institute, and Dr. N. Gunge, Dai-Nippon Sugar Manufacturing Co., Ltd., for supplying the haploid yeast strains and for their kind advice.

\section{REFERENCES}

1) T. Sai and M. Amaha: J. Gen. Appl. Microbiol., 11, 355 (1965).

2) S. Nagai, N. YAnAgishima and H. NAGAI: Bacteriol. Rev., 25, 404 (1961).

3) F. Sherman: Genetics, 48, 375 (1963).

4) C. J. Avers, C. R. Pfeffer and M. W. Rancourt: J. Bacteriol., 90, 481 (1965).

5) N. Gunge: Japan. J. Genetics, 41, 215 (1966). 
6) T. Sugimura, K. Okabe, M. Nagao and N. Gunge: Biochem. Biophys. Acta, 115, 267 (1966).

7) H. T. CzARnecki and E. L. VAN Engel: The Brewers Digest, March, 52 (1959).

8) S. NAGAI: Stain Technology, 40, 147 (1965).

9) M. Ogur, R. St. John and S. NagAi: Science; 125, 928 (1957).

10) M. Ogur and R. St. John: J. Bacteriol., 72, 500 (1956).

11) Dimotaki-Kourakou: Ann. Fals. Exp. Chim., 55, 149 (1962).

12) J. Ribereau-Gayon and E. Penaud: Analyse et Controle des Vins, Paris, 131 (1958).

13) F. Sherman and P. P. Slonimski: Biochem. Biophys. Acta, 90, 1 (1964).

14) T. Morita: Medicine and Biology, 72, (3), 166 (1966), in Japanese. 